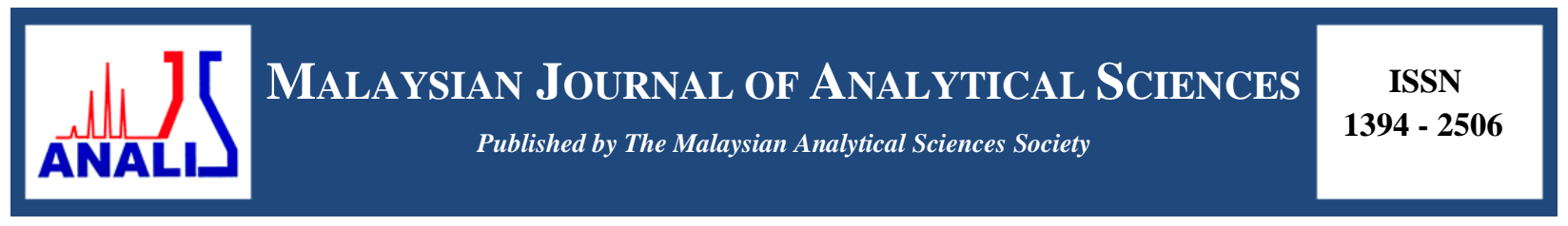

\title{
FRACTIONATION OF AQUEOUS EXTRACT OF Ficus deltoidea VAR. Kunstleri's LEAVES USING SOLID PHASE EXTRACTION METHOD FOR ANTICANCER ACTIVITY ON DU145 CELL LINE
}

\author{
(Pemeringkatan Ekstrak Akueus dari Daun Ficus deltoidea var. Kunstleri Menggunakan Kaedah \\ Pengestrakan Fasa Pepejal untuk Aktiviti Antikanser Pada Titisan Sel DU145) \\ Husnul Hanani Soib ${ }^{1}$, Harisun Yaakob ${ }^{1,2}$, Mohamad Roji Sarmidi ${ }^{2,3}$, Mohamad Norisham Mohamad Rosdi ${ }^{1}$ \\ ${ }^{I}$ Department of Bioprocess Engineering, Faculty of Chemical and Energy Engineering \\ ${ }^{2}$ Institute of Bioproduct Development \\ ${ }^{3}$ Innovation Centre in Agritechnology for Advanced Bioprocessing (ICA) \\ Universiti Teknologi Malaysia, 81310 UTM Skudai, Johor, Malaysia \\ *Corresponding author: harisun@ibd.utm.my
}

Received: 25 October 2017; Accepted: 22 January 2019

\begin{abstract}
Ficus deltoidea var. kunstleri or also known as 'Mas Cotek' belongs to the Moraceae family. It is widely used for postnatal treatment, anti-diabetic, anti-breast cancer, anti-nociceptive and anti-hypertension. In this study, the anticancer effects of flavonoid compounds from aqueous ethanolic fractions of $F$. deltoidea var. kunstleri leaves against prostate cancer cell lines, DU145 were investigated. The aqueous extract of $F$. deltoidea var. kunstleri was subjected for fractionation by solid phase extraction method by using various concentration of aqueous - ethanol ranging 20-99.8\%. The fractions (fraction I-IV) were screened to obtain the most active fraction through total phenolic and flavonoid contents and MTT assays. The induction of apoptosis was evaluated using Annexin V-FITC/PI while the morphological changes of DU145 cells was assessed using acridine orange/propidium iodide (AO/PI) staining method. HPLC, FTIR-ATR and LC-MS/MS analysis were conducted for identification and confirmation of bioactive compounds. Fraction I which was fractionated using $20 \%$ of ethanol exhibited the highest polyphenol contents and highest inhibition against DU145 at $100 \mu \mathrm{g} / \mathrm{mL}$ (45.45\%). Furthermore, cell viability of DU145 cells treated with crude extract of $F$. deltoidea var. kunstleri and its active fraction (I) were also compared using MTT assay. It was revealed that the crude and its active fraction $\mathbf{I}$ caused cell reduction through apoptotic machinery which was evidenced by the formation of apoptotic bodies, fragmentation, cell blebbing and cell shrinkage. These findings were confirmed by AO/PI staining method and Annexin V-FITC/PI. The presence of bioactive compounds of vitexin and isovitexin were identified by HPLC, FTIR-ATR and LC-MS/MS analysis. Positive correlations had been established between total phenolic and flavonoid content and anti prostate cancer activities. Therefore, these results suggest that flavonoids content of $F$. deltoidea var. kunstleri and its fraction I could potentially can be developed as an anti-cancer agent for prostate cancer.
\end{abstract}

Keyword: anti-cancer, antioxidant, F. deltoidea var. kunstleri, prostate cancer, vitexin

\section{Abstrak}

Ficus deltoidea var. kunstleri atau juga dikenali sebagai 'Mas Cotek' tergolong dalam keluarga Moraceae. Ia digunakan secara meluas untuk rawatan selepas bersalin, anti diabetes, anti kanser payudara, anti nosiseptif dan anti hipertensi. Dalam kajian ini, kesan antikanser oleh sebatian flavonoid daripada pemeringkatakan akueus etanol daun $F$. deltoidea var. kunstleri terhadap titisan sel kanser prostat, DU145 telah dikaji. Ekstrak akueus daripada $F$. deltoidea var. kunstleri telah dipilih untuk pemeringkatan oleh pengestrakan fasa pepejal menggunakan pelbagai kepekatan akueus - etanol berkadaran 20-99.8\%. Semua pemeringkatan (pecahan I-IV) telah disaring untuk mendapatkan pecahan yang paling aktif melalui jumlah kandungan fenol dan flavonoid serta ujian MTT. Induksi melalui apoptosis dinilai menggunakan Annexin V-FITC/PI manakala perubahan morfologi 


\section{Husnul Hanani et al: FRACTIONATION OF AQUEOUS EXTRACT OF Ficus deltoidea VAR. Kunstleri's LEAVES USING SOLID PHASE EXTRACTION METHOD FOR ANTICANCER ACTIVITY ON DU145 CELL LINE}

pada sel DU145 juga telah dinilai menggunakan kaedah pewarnaan acridin oren/propidium iodida (AO/PI). HPLC, FTIR-ATR dan LC-MS/MS analisis telah digunakan untuk mengenalpasti dan pengesahan sebatian bioaktif. Pecahan I yang terpecah menggunakan 20\% etanol mempamerkan kandungan polifenol tertinggi dan perencatan paling tinggi terhadap DU145 pada 100 $\mu \mathrm{g} / \mathrm{mL}$ (45.45\%). Tambahan pula, sel hidup DU145 yang telah dirawat oleh ekstrak mentah F. deltoidea var. kunstleri dan pecahan aktifnya (I) juga telah dibandingkan menggunakan ujian MTT. Ia telah membuktikan bahawa ekstrak mentah dan pecahan aktifnya I menyebabkan pengurangan sel melalui mesin apoptosis dimana telah dibuktikan melalui pembentukan badanbadan apoptosis, pemecahan, sel kembung dan pengecutan sel yang disahkan oleh kaedah pewarnaan AO/PI dan Anexin VFITC/PI. Kehadiran sebatian bioaktif vitexin dan isovitoksin telah dikenal pasti oleh analisis HPLC, FTIR-ATR and LC-MS/MS. Hubungan positif telah wujud di antara jumlah kandungan fenol dan flavonoid dan aktiviti anti-kanser prostat. Oleh itu, keputusan ini mencadangkan bahawa kandungan flavonoid $F$. deltoidea var. kunstleri dan pecahannya boleh dibangunkan sebagai agen anti-kanser untuk kanser prostat.

Kata kunci: anti-kanser, antioksida, F. deltoidea var. kunstleri, kanser prostat, vitexin

\section{Introduction}

Throughout the years, many studies have given attention to antioxidant activity along with phenolic and flavonoid content of plants [1-3]. Based on the findings, these bioactive constituents can inhibit the initiation, progression and spread of the cancer. As the cancer can be caused by a process of angiogenesis, it is believed to inhibit development of blood vessels for the growth of tumours [4]. Study has proved that plant containing higher amounts of phenolic and flavonoid may indicate the medicinal properties [5] which may act as anti-cancer [6] and anti-tumor [7]. Flavonoids are polyphenol compounds that have various pharmacological effects. They have the ability to induce certain enzyme like glucuronosyl transferase which can detoxify carcinogens in the body [8]. Besides, by alterating the gene expression, it enhanced the apoptosis and decreased the growth of neoplastic cells without harming healthy tissue.

Prostate cancer or typically known as a prostate adenocarcinoma is a prostatic malignancy which occurs at prostate gland of epithelial cells. It commonly develops at the posterior of the gland contrasting with benign enlargement where it occurs at the centre of prostate [9]. Globally, prostate cancer has become the most common non-skin cancer which attacks mostly of older men especially in western countries [10]. The progress of prostate cancer is slow as it takes longer time for invasion and metastasis. A normal cell can turn to cancer cell due to several factors such as mutation in its DNA either inherited or acquired by chemicals, viruses, radiations, diet intake, family history, environment and age. As DNA is mutated, it causes alteration in gene expression and consequently leads to activation of proto-oncogenes to oncogenes as wells as inactivation of tumors suppressor genes [11]. However, to date, the causes of the development of the prostate cancer still remain unknown and unclear.

Ficus deltoidea or locally knows as Mas Cotek is well distributed throughout the Southeast Asia and also can be found in Africa [12]. It comes from the family of Moraceae, genus Ficus and species of deltoidea. According to Corner [13], there are about 13 varieties of $F$. deltoidea which are differentiated based on morphological of leaves and figs. Studies revealed that $F$. deltoidea possessed antimicrobial effects [14], antinociceptive [15], antioxidant $[14,16,17]$ as well as anti-inflammatory [18, 19]. Moreover, based on the studies conducted by Zunoliza et al. [18], it proved that $F$. deltoidea contained high levels of vitexin and isovitexin. Vitexin is a class of lignan compounds and flavonoid glycoside found in certain plants [20]. Vitexin induced anti-tumor [3] and exerted cytotoxicity activity by proapoptotic process which mediated by a decreased Bcl-2/Bax ratio together with activation of caspases and prevent cells from undergoing angiogenesis and metastasis [21].

Solid phase extraction (SPE) is one of the famous techniques used for fractionation especially for antioxidant compounds [22-25]. It is a simple and low cost method as compare to other liquid-liquid extraction method while it can reduce the usage of the sample and solvent [26, 27]. SPE have the ability to retain compound of interest on the sorbent while matrix interferences will be eluted from the cartridge via washing step; and later, the compounds of interest will be eluted with stronger solvent [25]. Basically, there are three main principles in SPE comprising of loading the sample, washing away undesired compounds and eluting desired compounds. The sample must be in liquid state so that the analytes in the sample will bind to the solid sorbent before the elution step. To wash off and collect the compounds of interest, most studies have used different types of solvents like ethyl acetate, hexane or 
dichloromethane [28, 29] or using the same type of solvent with different polarity [23]. Besides, Patelinc et al. [23] have developed different types of eluent solvent ranging from $30 \%$ ethanol to $70 \%$ ethanol in order to determine the activity of phenolic compounds from different fractions of Propolis on antioxidant and cellular metabolic effects in yeast. Theoretically, increasing polarity of the eluent will extract more polar compounds. Indeed, the selection of the solvent used for elution highly affects the group of compounds to be extracted [30, 31].

This study was conducted to explore the fractionation process of $F$. deltoidea var. kunstleri crude extract using solid phase extraction method and the relationship between antioxidant and anticancer activities in view of prostate cancer cell line, DU145.

\section{Materials and chemicals}

\section{Materials and Methods}

Vitexin, isovitexin, 2,2-diphenyl-1picrylhydrazyl (DPPH), thiazolyl blue tetrazolium bromide (MTT) was purchased from Sigma-Aldrich ${ }^{\circledR}$, USA. HPLC-grade methanol, formic acid, ethanol, Folin-Ciocalteu reagent was purchased from Merck ${ }^{\circledR}$, Germany. Penicillin streptomycin, Dulbecco’s modified eagle medium (DMEM), trypsin EDTA, phosphate buffered saline (PBS), fetal bovine serum (FBS) were obtained from GIBCO ${ }^{\circledR}$, USA.

\section{Plant material}

The leaves of variety of $F$. deltoidea var. kuntleri were purchased from Moro Seri Utama Enterprise, Batu Pahat, Johor, Malaysia. It was authenticated by a botanist, Dr Shamsul Khamis from Institute of Bioscience, Universiti Putra Malaysia (UPM). A voucher specimen (SK 2312/13) of plant was deposited in Institute of Bioproduct Development, Universiti Teknologi Malaysia for further reference.

\section{Plant extraction}

The ground leaves of variety $(7 \mathrm{~g})$ were boiled with $300 \mathrm{~mL}$ of distilled water at $90{ }^{\circ} \mathrm{C}$ for about 1 hour and 50 minutes. The extract was filtered using filtration paper Whatman (No.1) and concentrated under a reduced temperature at $40{ }^{\circ} \mathrm{C}$ using rotary evaporator. Then, the sample was freeze-dried (Brand: Labconco) and stored at $20{ }^{\circ} \mathrm{C}$ until further use.

\section{Fractionation by solid phase extraction method}

The method implied was based on method developed by Patelinc et al. [23] with slightly modification in which the eluting solvents from 20, 40, 60 and $99.8 \%$ of ethanol $(\mathrm{EtOH})$ were used to collect different fractions of polarity which assigned as fraction I-IV. Previously, this variety was chosen based on in vitro screening results consisted of total phenolic and flavonoid content, DPPH analysis as well as MTT assay as mentioned in previous study [32]. An amount $10 \mathrm{mg}$ of standardized aqueous extract of $F$. deltoidea var. kuntleri was dissolved in $1 \mathrm{~mL}$ of distilled water and vortex thoroughly. The bonded silicas $\mathrm{C}_{18}$ of SPE cartridge (Phenomenex ${ }^{\circledR}$, USA) was pre-conditioned with 5 $\mathrm{mL}$ of methanol followed by $5 \mathrm{~mL}$ of distilled water. The fractions I-IV were collected using eluent co-solvent of 20, 40, 60 and $99.8 \%$ of EtOH (Figure 2). All collected fractions were dried at $40{ }^{\circ} \mathrm{C}$ in centrifugal evaporator and stored at $-20{ }^{\circ} \mathrm{C}$ until further use.

\section{Determination of total phenolic content}

A total phenolic content (TPC) was carried out using Folin-Ciocalteu assay as explained by Singleton et al. [33]. Gallic acid was used as standard ranging from $0.02-0.10 \mathrm{mg} / \mathrm{mL}$. An amount of $5 \mathrm{~mL}$ of $10 \%$ of Folin-Ciocalteu reagent was added into $1 \mathrm{~mL}$ of the fractions or standard. Then, they were mixed for five minutes. After that, $4 \mathrm{~mL}$ of $7.5 \%$ sodium carbonate, $\mathrm{NaCO}_{3}$ solution was added and left for 60 minutes. The absorbance was read at $760 \mathrm{~nm}$ by using UV-Vis spectrophotometer. A gram of garlic acid equivalents (GAE) per gram of extract was used as results of total phenolic content.

\section{Determination of total flavonoid content}

A total flavonoid content (TFC) was performed based on the method determined by Atanassova et al. [34] with some modification. An amount of $1 \mathrm{mg} / \mathrm{mL}$ of sample or standard stock solution was mixed up with $0.3 \mathrm{~mL}$ of sodium nitrate, $\mathrm{NaNO}_{2}$. After five minutes, $0.3 \mathrm{~mL}$ of aluminium chloride, $\mathrm{AlCl}_{3}$ was added and the mixture was left for six minutes. Next, $2 \mathrm{~mL}$ of sodium hydroxide, $\mathrm{NaOH}$ was added into mixture. The analyses are then 


\section{Husnul Hanani et al: FRACTIONATION OF AQUEOUS EXTRACT OF Ficus deltoidea VAR. Kunstleri's LEAVES USING SOLID PHASE EXTRACTION METHOD FOR ANTICANCER ACTIVITY ON DU145 CELL LINE}

performed in triplicate and the standard curve with serial catechin solutions $0.05,0.10,0.25$ and $0.50 \mathrm{mg} / \mathrm{mL}$ was used for calibration. The absorbance was read at $510 \mathrm{~nm}$ and the results are expressly as a gram of catechin equivalents (CE) per gram of extract.

\section{Cell culture: In vitro screening of different fractions}

The prostate cancer cell line (DU145) was obtained from American Type Culture Collection (Maryland, USA). The cells were cultured with media supplemented with DMEM, $1 \%$ of streptomycin and $10 \%(\mathrm{v} / \mathrm{v})$ of fetal bovine serum. The cells were incubated at $37{ }^{\circ} \mathrm{C}$ in humidified atmosphere of $5 \% \mathrm{CO}_{2}$.

\section{Cell viability using MTT (3-[4, 5-dimethylthiazol-2-yl]-2, 5 diphenyl tetrazolium bromide) assay}

MTT assay is a routine method for screening the toxicity effects of extract or certain compound on cells. The method is based on the reduction of certain enzyme called dehydrogenase enzymes of viable cells through mitochondrial activity [35]. The cells at 70-80\% of confluence were trypsinized and seeded into 96-well plate with density of $1 \times 10^{5}$ cells $/ \mathrm{mL}$. Cells were incubated for 48 hours for treatments. Afterwards, cells were resuspended with medium (without serum) for starvation and reincubated for 3-4 hours. Next, $90 \mu \mathrm{L}$ fresh medium and $10 \mu \mathrm{L}$ MTT solution $(5 \mathrm{mg} / \mathrm{mL})$ were added and incubated for another 4 hours. After that, the media was removed and $200 \mu \mathrm{L}$ of DMSO was added to allow dissolution of purple MTT. The optical density of solution was measured at $570 \mathrm{~nm}$ using ELISA reader.

$$
\text { Percentage of viable cell }(\%)=\frac{\text { Optical density of sample }}{\text { Optical density of control }} \times 100
$$

Acridine orange and propidium iodode (AO/PI) staining assay by florescence microscope Cells of DU145 were seeded and treated with $100 \mu \mathrm{g} / \mathrm{mL}$ of fraction I and $93.11 \mu \mathrm{g} / \mathrm{mL}$ of standardized aqueous of F. deltoidea var. kuntleri ( $\mathrm{IC}_{50}$ value - data not shown). After 48 hours incubated with the treatments, the growth medium was discarded. The cells were then stained with the dye mixture containing $10 \mu \mathrm{L}$ of $1 \mathrm{mg} / \mathrm{mL}$ AO and 10 $\mu \mathrm{L}$ of $1 \mathrm{mg} / \mathrm{mL}$ of PI. The stained cells were examined and observed using inverted florescence microscope.

\section{Annexin V-FITC/PI by flow cytometry}

The cells were washed with cold PBS before resuspended in $1 \mathrm{x}$ binding buffer at a concentration of $1 \times 10^{5}$ cells $/ \mathrm{mL}$. Then, $100 \mu \mathrm{L}\left(1 \times 10^{5}\right.$ cells $\left./ \mathrm{mL}\right)$ of cells were transferred into a $5 \mathrm{~mL}$ culture tube followed by $5 \mu \mathrm{L}$ of FITC annexin V and $5 \mu \mathrm{L}$ PI. Next, the tubes were vortex and incubated for 15 minutes at room temperature in the dark. After that, $400 \mu \mathrm{L}$ of $1 \mathrm{x}$ binding buffer were added to each tube and the cells were analyzed by flowcytometry within 1 hour.

\section{Quantitative analysis of most active fraction by HPLC}

HPLC analysis was performed based on the previous study conducted by Elham et al. [36] with slightly modification. In this method, two types of solvent system used which were HPLC-grade methanol (absolute) and formic acid (1\%) as well as two standards which were vitexin and isovitexin. A reversed-phase Nucleosil $\mathrm{C}_{18}$ column was maintained at $25{ }^{\circ} \mathrm{C}$ while mobile phase at flow rate of $1 \mathrm{~mL} / \mathrm{min}$. The wavelength used was $330 \mathrm{~nm}$ and the separation time estimated was 30 minutes.

\section{Detection of compounds by Fourier transform infrared spectroscopy- attenuated total reflectance}

FTIR spectra were obtained using Perkin Elmer Spectrum 400 Infrared spectroscope coupled with an air-cooled deuterated triglycine sulphate (DTGS) detector. Attenuated total reflectance (ATR) scan technique was used on all of the samples. The infrared measurements were taken at resolution $4 \mathrm{~cm}^{-1}$ with 16 inferograms co-added before Fourier transformation. The data were recorded at mid-IR range of $650-4000 \mathrm{~cm}^{-1}$. The samples used for the analysis in a dried form.

\section{Identification of active compound of most active fraction by LC-MS/MS}

Detection of compounds presence in the active fraction was identified using ultra performance liquid chromatography (UPLC), Waters Acquity (Milford, MA), coupled with triple quadrupole-linear ion trap tandem 
mass spectrometer (Applied Biosystems 4000 Q TRAP; Life Technologies Corporation, Carlsbad, CA) with an electrospray ionisation (ESI) source. A column of $\mathrm{C}_{18}$ reserved phase Acquity column (150 $4.6 \mathrm{~mm}, 1.7 \mathrm{~lm}$ ).

\section{Statistical analysis}

Analysis of variance (ANOVA one-way) was used to analyze the data from the experiments. The data was compared with the identified control specific to negative control and the experiments were carried out triplicate. Pearson's correlation coefficient test was used to assess correlations between means and $p<0.05$ was set as the limits of significance.

Total phenolic and flavonoid content

\section{Results and Discussion}

Fraction I demonstrated the highest contents of phenolic (53.284 $\pm 0.023 \mathrm{mg} \mathrm{GAE} / \mathrm{g})$ and flavonoid (506.291 \pm $0.003 \mathrm{mg} \mathrm{CE} / \mathrm{g}$ ) followed by fraction $\mathbf{I I}>$ III $>$ IV.

Table 1. Total phenolic and flavonoid contents of the fractions of $F$. deltoidea var. kunstleri extracts expressed in terms of gallic acid equivalent ( $\mathrm{mg}$ of GAE/g of extract)

\begin{tabular}{lcc}
\hline Fractions & TPC $(\mathbf{m g}$ GAE/g) & TFC $(\mathbf{m g ~ C E} / \mathbf{g})$ \\
\hline I & $53.284 \pm 0.023$ & $506.291 \pm 0.003$ \\
II & $33.644 \pm 0.001$ & $363.834 \pm 0.001$ \\
III & $32.223 \pm 0.011$ & $333.032 \pm 0.003$ \\
IV & $27.954 \pm 0.034$ & $322.099 \pm 0.003$ \\
\hline
\end{tabular}

\section{MTT (3-[4, 5-dimethylthiazol-2-yl]-2, 5 diphenyl tetrazolium bromide) assay}

The viability of cells treated with four fractions eluted from different polarities of EtOH/water as eluents was examined in Table 2 and Figure 1. The highest inhibition of prostate cancer was established at fraction $\mathbf{I}$ which was eluted by $20 \%$ of EtOH. The inhibition of DU145 cells decreased as the polarity of eluent used increased (20\% $99.8 \%$ of EtOH). The results were significant differences as compared to several controls $(p<0.05)$. Unfortunately, the effect of cytotoxicity of vitexin and curcumin were similar $(p>0.05)$. The result suggested that the higher polarity of eluent trapped many polar compounds such as flavonoids, phenols and tannins which are believed to enhance the effect of cytotoxicity on cancer cells. The trend of the cell viability also increases as less polar eluents was used. It was aligned with the method used for fractionation as it was widely influenced the compounds extracted from the fractions. Three types of standards used which were vitexin, paclitaxel-synthetic drug and curcumin (contained 95\% curcuminoids) and the results showed that paclitaxel possessed the highest inhibition as compared to the natural compound unlike vitexin and curcumin. In addition, the inhibition of DU145 by fraction I was significantly higher as compared to vitexin and curcumin alone. 


\section{Husnul Hanani et al: FRACTIONATION OF AQUEOUS EXTRACT OF Ficus deltoidea VAR. Kunstleri's LEAVES USING SOLID PHASE EXTRACTION METHOD FOR ANTICANCER ACTIVITY ON DU145 CELL LINE}

Table 2. The effects of ethanolic fractions after 48 hours of treatments on DU 145 cell lines

\begin{tabular}{lc}
\hline Treatments & $\begin{array}{c}\text { Mean No. of Viability Cells } \\
(\%) \pm \text { S.E.M }\end{array}$ \\
\hline Fraction I $-20 \%$ & $54.55 \pm 0.36^{a, b, c}$ \\
Fraction II $-40 \%$ & $86.68 \pm 0.35^{a, b, c}$ \\
Fraction III $-60 \%$ & $117.15 \pm 0.44^{a, b, c}$ \\
Fraction IV $-99.8 \%$ & $123.99 \pm 0.67^{a, b, c}$ \\
${ }^{a}$ Paclitaxel $(0.1 \mu \mathrm{M})$ & $50.91 \pm 0.17^{a, c}$ \\
${ }^{b}$ Vitexin $(100 \mu \mathrm{g} / \mathrm{mL})$ & $90.29 \pm 0.35^{a}$ \\
${ }^{c}$ Curcumin $(100 \mu \mathrm{g} / \mathrm{mL})$ & $89.63 \pm 0.09^{a}$ \\
\hline
\end{tabular}

The $p$-value $(<0.05)$ of the treatments were compared with control groups.

Different letter explained the significantly the effects of the fractions compared to control (mean, $\mathrm{n}=3$ ).

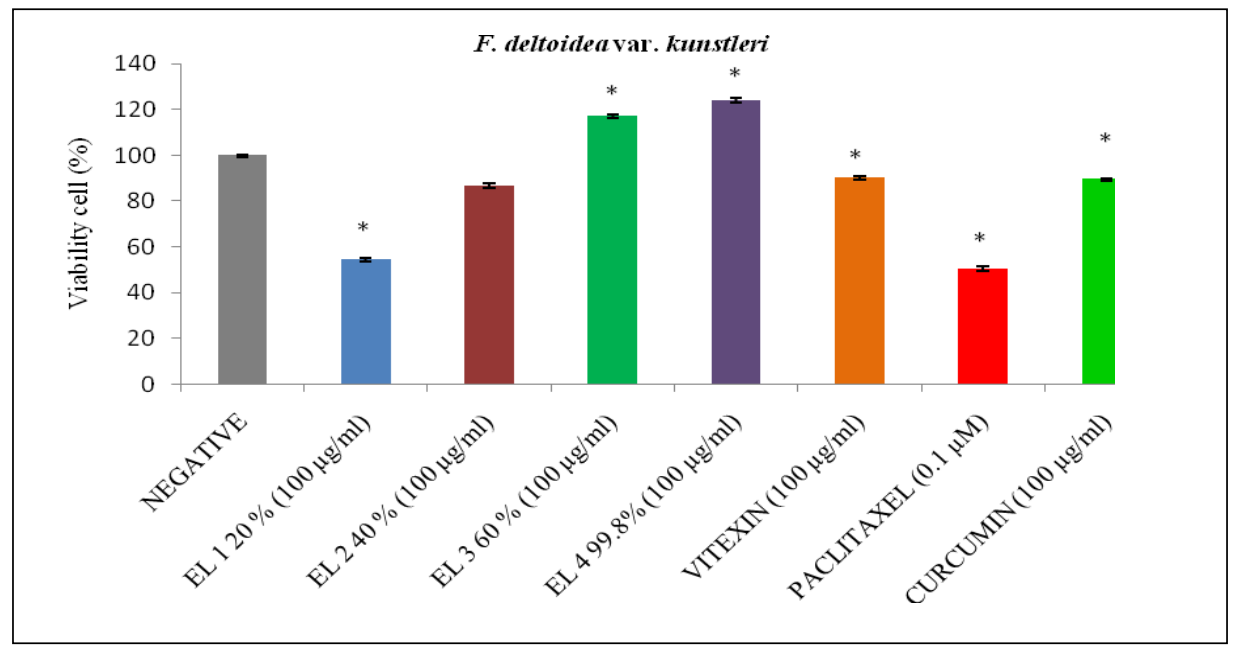

\footnotetext{
'*' indicate that the results were significantly different for both controls $(p<0.05)$. The data is presented as mean $(\mathrm{n}=3)$ from triplicate analysis and the error bar indicate standard deviation. EL 1 = fraction I of $20 \% \mathrm{EtOH}, \mathrm{EL} 2=$ fraction $\mathbf{I I}$ of $40 \% \mathrm{EtOH}$, EL 3 = fraction III of $60 \%$ EtOH, EL 4 = fraction IV of $99.8 \%$ EtOH.
}

Figure 1. The effects of various treatments on the viability of DU145 cell after 48 hours treatment. The fractionated extract of $F$. deltoidea var. kunstleri and active compounds (vitexin and curcumin) were compared to the negative control (untreated cell) as well as positive control (paclitaxel).

\section{Solid phase extraction}

The importance of SPE method to enhance the concentration of polyphenol derived from crude extract was analyzed in this study. The method was considered as cost effective as it could reduce the usage of the solvent and the sample compared to other liquid-liquid chromatography technique. SPE method cleaned up the crude extract by removing unnecessary components while retaining the respective compounds [37]. As proven, the total phenolic and flavonoid contents from the $F$. deltoidea var. kunstleri's fractions were higher as compared to the crude (data not shown). Moreover, the used of reverse phase of $\mathrm{C}_{18}$ cartridge was eluted more phenolic and flavonoid compounds. Increase 
polarity of the eluent, the more polar compounds will be eluted and collected [30, 31]. A study done by Sultana et al. [38] had reported that the antioxidants compounds like phenolic and flavonoids are well extracted using aqueous organic solvents rather than absolute organic solvent. It was proved when $99.8 \%$ of EtOH had extracts lowest polyphenols compounds while the mixture of $\mathrm{EtOH} /$ water had extracts highest respective compounds. As for comparisons, the total polyphenolic content of the fractions was higher compared to the crude previously. It is due to different compositional mixtures of the solvent eluents (EtOH/water) facilitate in breaking the cell membranes of the compounds to be eluted [39]. Moreover, it also denoted that solid phase extraction method is effective method for intensify, separation and collection more polyphenol compounds which can enhance the isolation process if involved [40, 41].

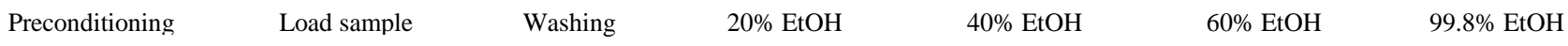
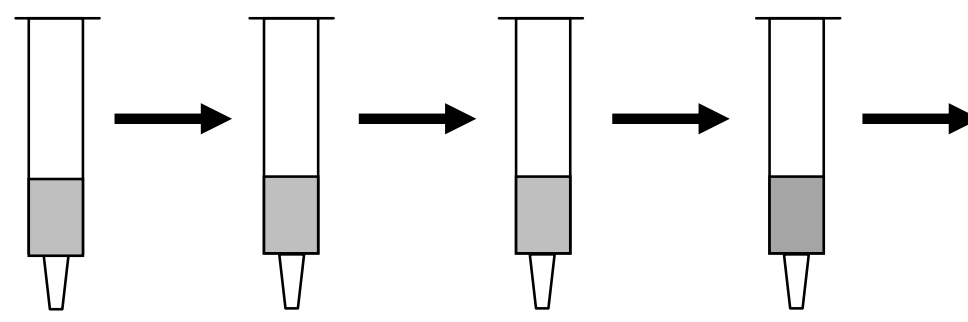

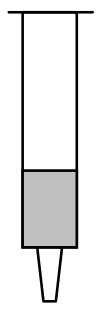

Fraction I

Fraction II

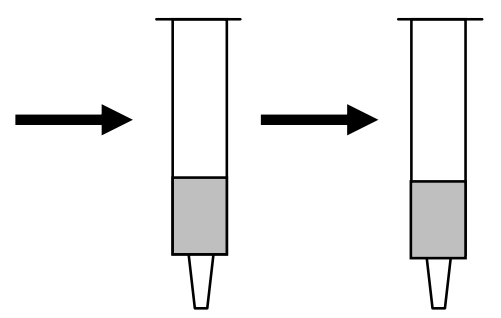

Figure 2. Preparation of fractions (I - IV) extracted from different polarity of eluents of EtOH/water by solid phase extraction

Correlation between anti cancer activity and total phenolic and flavonoid content

Table 3 showed the correlation among antioxidant and anti-cancer activities against DU145. The correlation coefficient number was between -1 to 1 . As the number of correlation coefficient obtained from linear relationship nears to 1 , it indicates the stronger relationship between two variables. Meanwhile, positive (+) indicate the positive direction of relationship. It showed that, the total phenolic content was positively correlated to total flavonoid content $\left(\mathrm{y}=7.509+105.18, r^{2}=0.993\right)$ whereas negative correlation was observed in total phenolic $(\mathrm{y}=-2.619 \mathrm{x}+$ $\left.191.87, r^{2}=-0.928\right)$ and flavonoid $\left(\mathrm{y}=-0.353 \mathrm{x}+230.33, r^{2}=-0.946\right)$ content corresponding to toxicity activity in view of MTT assay.

Table 3. The Pearson correlation coefficients $(r)$ among antioxidant and anti-cancer activities against DU145 cell line

\begin{tabular}{lcc}
\hline Relationship & Correlation coefficients (r) & $\boldsymbol{p}$ (2-tailed) \\
\hline Total phenolic and flavonoid content & 0.993 & 0.007 \\
Total phenolic content and toxicity activity & -0.928 & 0.072 \\
Total flavonoid content and toxicity activity & -0.946 & 0.054 \\
\hline
\end{tabular}

It was proven by mean high percentage of radical scavenging activities could retard and inhibit the growth of cancer. Studies have confirmed that the occurrence of cancer is due to the presence of unstable molecules in the body known as reactive oxygen species (ROS) [42]. ROS comprises of singlet oxygen, superoxide anion radical and the peroxide anion. When the body contains high free radical, it will give harm and cause damage to the cellular or genomic in the prostate cell and later lead to the development of cancer. At this point, the role of antioxidant is to stabilize the free radical. Based on the findings, the phenolic compounds can inhibit the initiation, progression and deter the spread of the cancer. Other than that, it also had been stated by Yizhong et al. [43] in their article that 


\section{Husnul Hanani et al: FRACTIONATION OF AQUEOUS EXTRACT OF Ficus deltoidea VAR. Kunstleri's LEAVES USING SOLID PHASE EXTRACTION METHOD FOR ANTICANCER ACTIVITY ON DU145 CELL LINE}

antioxidant activities of phenolic compounds had been proved to have a connection on anti-cancer activities. It can be proved when the consumption of traditional Chinese medicinal plants could lower the incidence of cancer. Besides, they also added that the stronger antioxidant activities of plants contain higher total phenolic content leading to a stronger correlation to the anticancer activities.

\section{Morphology evaluation by acridine orange and propidium iodode (AO/PI) staining assay}

Nuclear morphology changes on the DU145 cells were further examined using AO/PI double staining method whereby apoptotic, viable and necrotic features were determined (Figure 3a-3d). The study revealed that crude extract of $F$. deltoidea var. kunstleri and its active fraction I posses' cytotoxicity effect related to apoptosis compared to control (Figure 3a). A normal appearance of cells was observed at untreated cells while morphologies of the cell treated with $F$. deltoidea var. kunstleri and its active fraction $\mathbf{I}$ undergoes certain changes which indicated the event of apoptosis. It included formation of apoptotic bodies, fragmentation, cell blebbing and chromatin condensation.
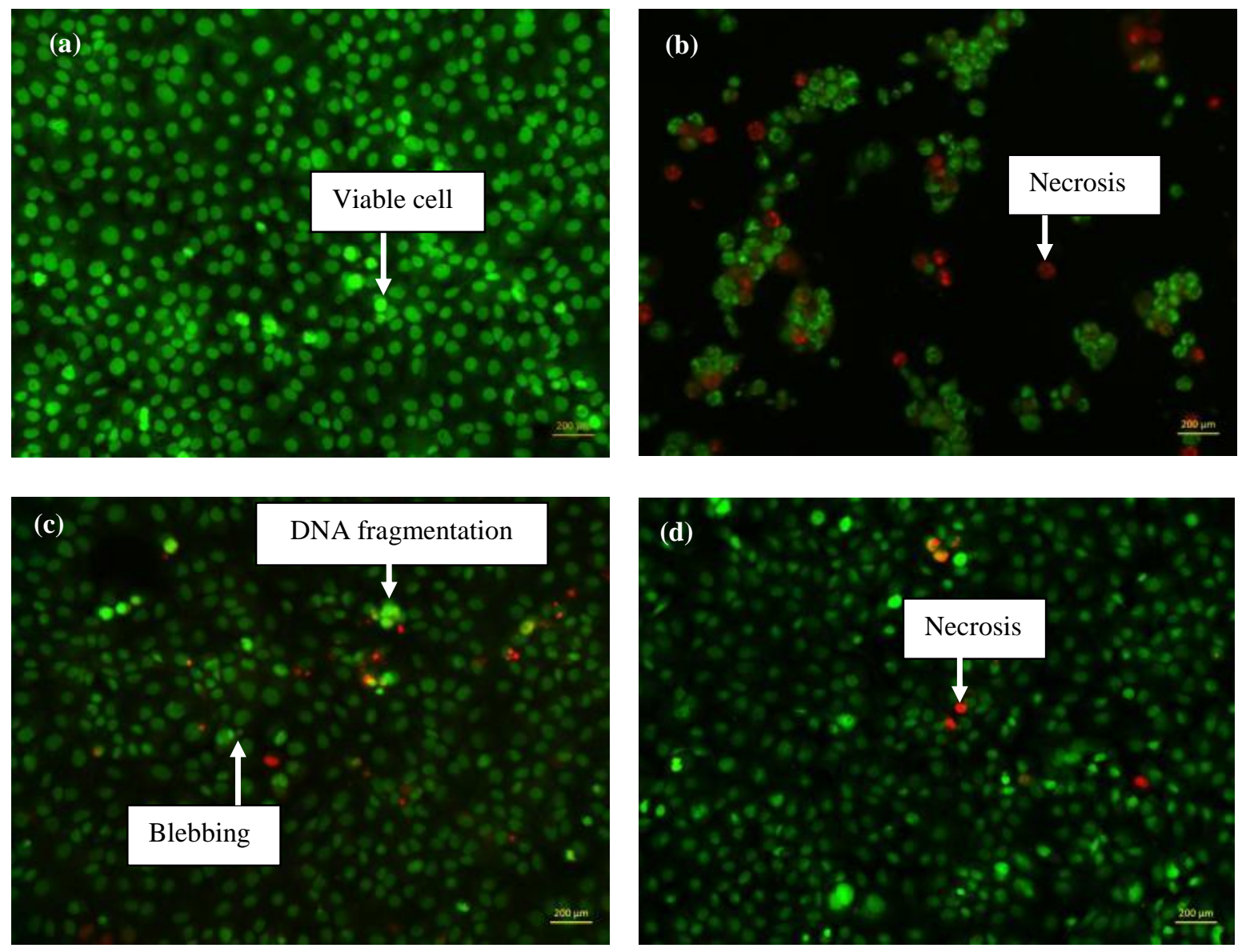

Figure 3. Morphological changes of DU145 cells with apoptotic feature were observed. The cells were treated with crude extract of $F$. deltoidea var. kusntleri and its active fraction, fraction $\mathbf{I}$ for 48 hours. The stained cells were viewed using a fluorescent microscope (x200). (a) untreated DU145 cells, (b) positive control Paclitaxel (c), crude extract of $F$. deltoidea var. kunstleri and (d) active fraction $\mathbf{I}$ 


\section{Annexin V-FITC/PI by flowcytometry}

In this study, a quantitative analysis of cells undergoing apoptosis was performed by using Annexin V-FITC/PI assay. Annexin-V FITC/PI assay is a method based on the principle of translocation of phosphatidylserine (PS) during apoptosis in which this assay uses fluorescent dyes (annexin and propidium iodide) to detect type of early apoptosis before morphological cells changes. Apoptosis is a physiological process of cell death by which it helps body to maintain the number of proliferative cells. Thus, the numbers of cells are equals to the number of cell death. At a normal condition, the cells which were embeded with the asymmetrical membrane are maintained by ATPdependant named flippases and floppases [44]. However, when there is an apoptosis event, the enzyme called flippase caused translocation of phosphatidylserine (PS) - types of phospholipid from inner layer of cytosol to the outer layer of membrane. The exposure of PS on outer layer caused the annexin (high affinity) to bind with it.

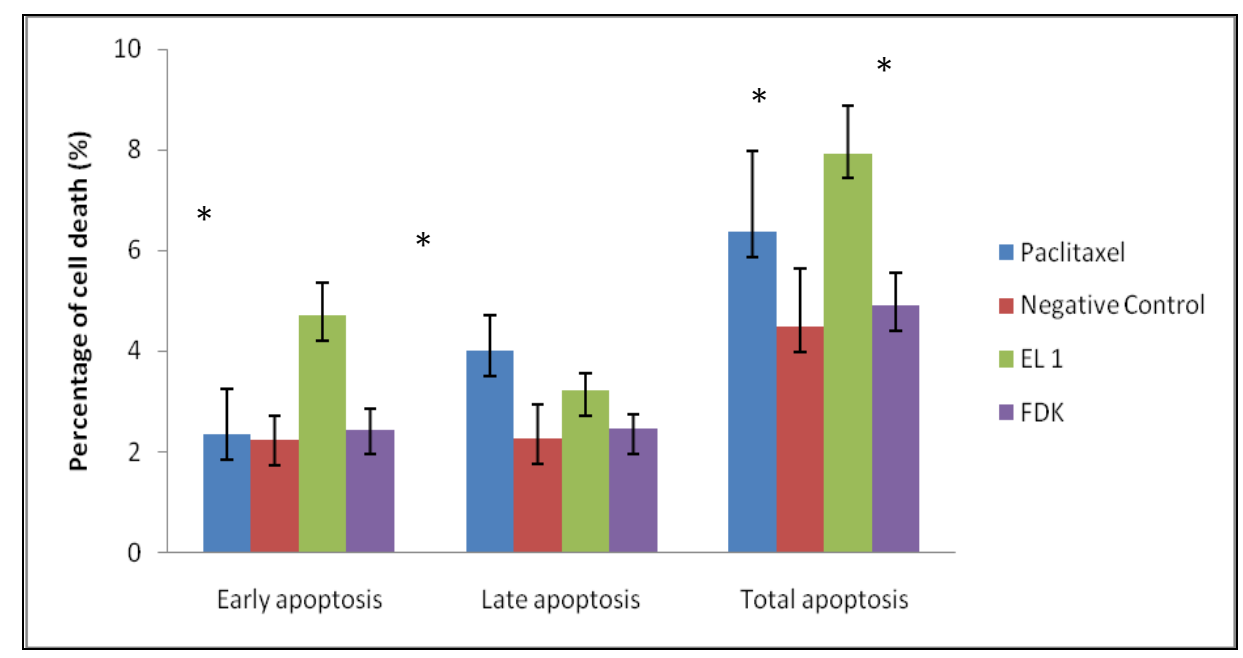

' $*$ ' indicate that the treatment was significant to negative control of untreated cell $(p<$ $0.05)$. EL $1=$ fraction $\mathbf{I}$ of $20 \% \mathrm{EtOH}, \quad \mathrm{FDK}=F$. deltoidea var. kunstleri

Figure 4. Assessment of apoptosis by annexin-V/FITC on prostate cancer cell line DU145 after 48 hours of incubation. The percentage of total number of cell death was calculated based on summed up of the number of early stage of apoptotic cells (annexin V+/PI-) and late stage of apoptotic cells (annexin $\mathrm{V}+/ \mathrm{PI}+)$.

As shown in Figure 4, early stage apoptotic cells (annexin V+/PI-) induced by fraction I was statistically higher than the control while in late stage apoptotic cell (annexin $\mathrm{V}+/ \mathrm{PI}+)$, paclitaxel was statistically higher than control $(p$ $<0.05$ ). As a whole, paclitaxel and fraction I showed significant difference compared to negative control in view of total percentage of early and late apoptosis. Despite the significant effect of fraction, I to induce apoptosis, the numbers of viable cells found were quite high (80-90\%). It was presumed that the cell death of DU145 induced by fraction I and $F$. deltoidea var. kunstleri does not occurred via the apoptosis pathway. It was aligned with other study which suggested that the aqueous extract of $F$. deltoidea promoted cell detachment rather than causing cell death. To some extent, the aqueous extract could cause apoptosis at higher concentration $1000 \mu \mathrm{g} / \mathrm{mL}$. In other related studies, Fattahi et al. [45] had obtained the $\mathrm{IC}_{50}$ of $2 \mathrm{mg} / \mathrm{mL}$ when using aqueous extract. It was suggested that, most probably the compound which exhibited anti-cancer properties originated from non-polar compounds compared to polar compounds. Other than that, study has revealed that the annexin-V FITC/PI may not be an absolute method to show apoptosis events as it also can determine the pathological effects $[46,47]$.

\section{FTIR-ATR analysis of active fraction I}

It was suggested that the anti-cancer effect of fraction I towards DU145 was due to the presence of polyphenolic compounds which were confirmed by FTIR-ATR analysis (Figure 5). FTIR-ATR analysis was done to support the presence of compounds where the analysis will observe the presence of functional group found in the fractions of 


\section{Husnul Hanani et al: FRACTIONATION OF AQUEOUS EXTRACT OF Ficus deltoidea VAR. Kunstleri's LEAVES USING SOLID PHASE EXTRACTION METHOD FOR ANTICANCER ACTIVITY ON DU145 CELL LINE}

$20 \% \mathrm{EtOH}$ (Figure 4.12). The functional group of phenolic $-\mathrm{OH}$ was observed at peak of $3259 \mathrm{~cm}^{-1}$, alkene $\mathrm{C}=\mathrm{C}$ at peak $1602 \mathrm{~cm}^{-1}$, an asymmetric stretch nitro compound $\mathrm{N}-\mathrm{O}$ at peak $1517 \mathrm{~cm}^{-1}$, an asymmetrical bending vibration of $\mathrm{C}-\mathrm{H}$ at $1393 \mathrm{~cm}^{-1}\left(\mathrm{CH}_{3}\right)$. In addition, symmetrical C-O-C stretching vibration also found at peak of $1050 \mathrm{~cm}^{-1}$ and $\mathrm{C}-\mathrm{H}$ bonded at peak $900-675 \mathrm{~cm}^{-1}$.

\section{HPLC analysis}

The quantifications of dry weights were calculated based on the linearity of calibration curves of vitexin and isovitexin $(1 \mu \mathrm{g} / \mathrm{mL}-100 \mu \mathrm{g} / \mathrm{mL})$ in which $\mathrm{x}$ is the concentration of the compound while y is a peak area. Vitexin was showed good linearity with regression equation $\left(\mathrm{y}=22955 \mathrm{x}+48627, r^{2}=0.995\right)$ as well as isovitexin with regression equation $\left(\mathrm{y}=33932 \mathrm{x}+46459, r^{2}=0.996\right)$. It has been recognized that the active fraction $\mathbf{I}$ contained of vitexin and isovitexin (Figure 6). The dry weight of compounds obtained were $5.05 \pm 0.13 \mathrm{mg} / \mathrm{g}$ and $0.42 \pm 0.01$ $\mathrm{mg} / \mathrm{g}$. In respect to vitexin, the result was higher compared to the study done by Farsi et al. [12] where they found $4.27 \mathrm{mg} / \mathrm{g}$ of aqueous extracts of $F$. deltoidea (not mentioned variety). It was promoted that the used of homogenous mixture of 20\% EtOH/water as eluents extracted high percentage of vitexin. Likewise, with the mixture of eluents, it can preserve the composition of vitexin extracted initially by the crude (data not shown). It may due to the closeness of polarity in which the mixture contains high polarity attributed from $80 \%$ water. Nevertheless, after fractionation occurred at $20 \% \mathrm{EtOH}$, it had higher competency to elute more isovitexin $(0.42 \mathrm{mg} / \mathrm{g})$ from the sample and cause it to increase twice compared to the crude $(0.24 \mathrm{mg} / \mathrm{g})$.

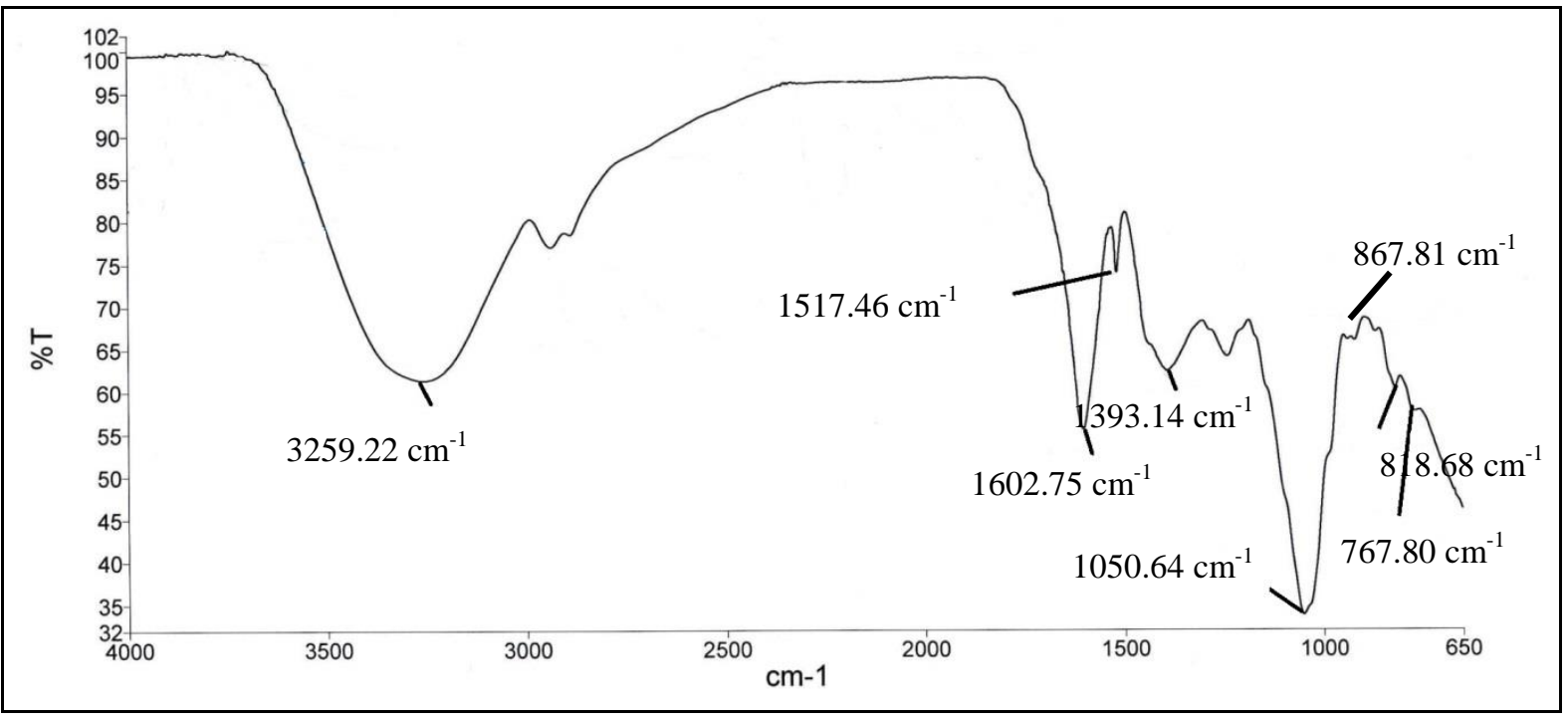

Figure 5. FTIR-ATR Spectrum of active fraction I (20\% EtOH)<smiles>O=c1cc(-c2ccc(O)cc2)oc2c([C@@H]3O[C@H](CO)[C@@H](O)[C@H](O)[C@H]3O)c(O)cc(O)c12</smiles><smiles>O=c1cc(-c2ccc(O)cc2)oc2cc(O)c(C(O)OC3C(O)CC(O)C(O)C3O)c(O)c12</smiles> 

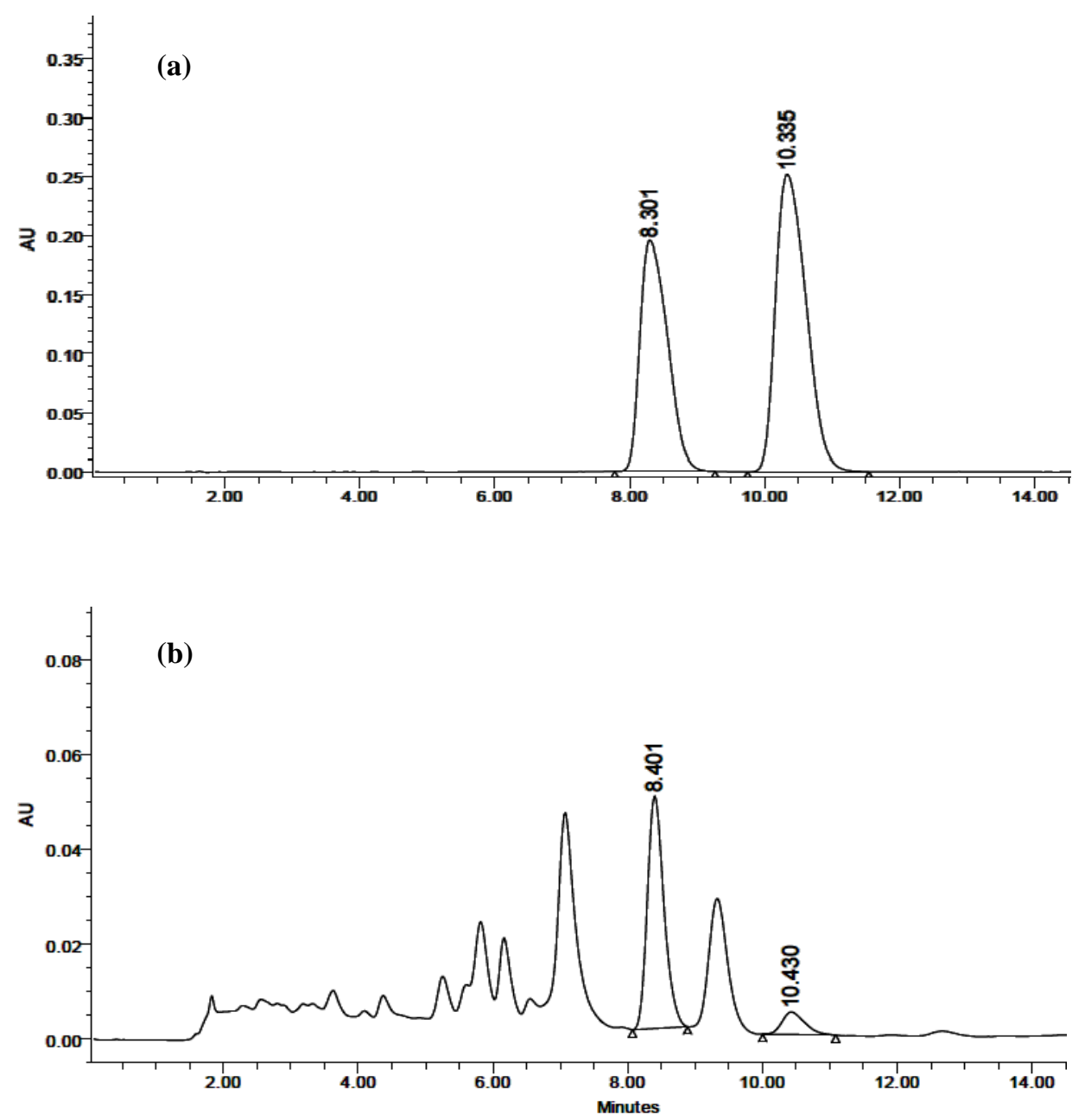

Figure 6. Chromatograms of vitexin (1) and isovitexin (2) found in fraction I monitored at wavelength of $330 \mathrm{~nm}$. A, standard; B, Active fraction I

\section{LC-MS/MS}

In this study, identification of active compound Apigenin-8-C-glucoside flavones (vitexin) was identified in active fraction I (Figure 7). It was characterized by $[\mathrm{M}-\mathrm{H}]^{-}$based on the MS fragment at $\mathrm{m} / \mathrm{z} 431,341,311,269$. 


\section{Husnul Hanani et al: FRACTIONATION OF AQUEOUS EXTRACT OF Ficus deltoidea VAR. Kunstleri's LEAVES USING SOLID PHASE EXTRACTION METHOD FOR ANTICANCER ACTIVITY ON DU145 CELL LINE}

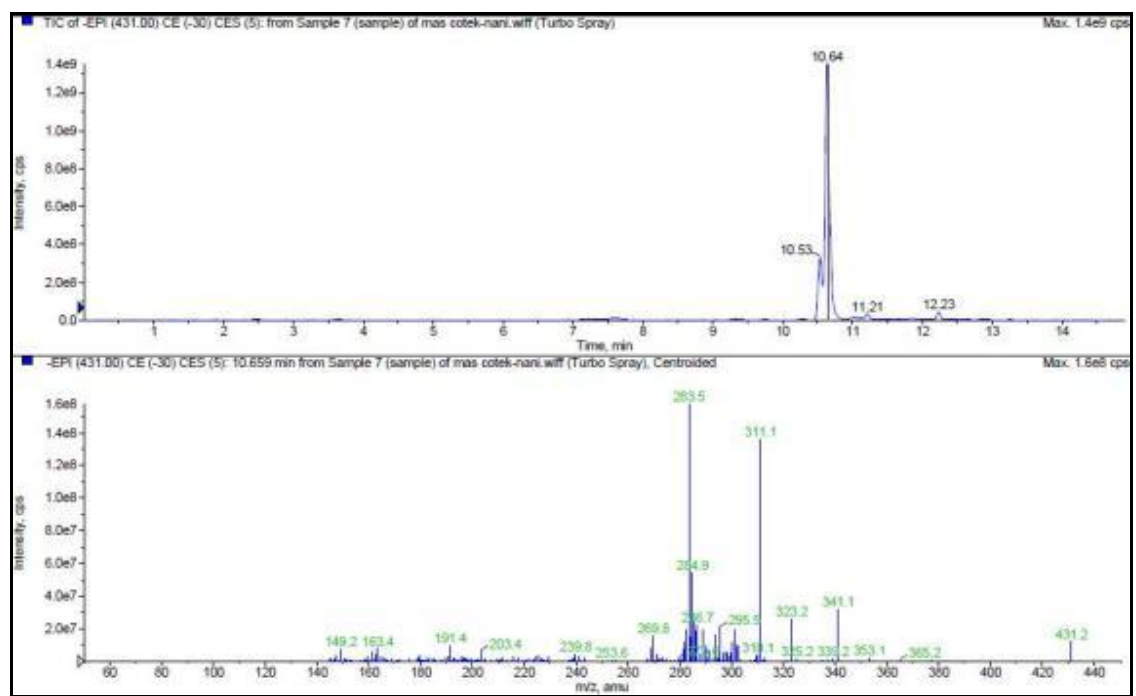

Figure 7. The EPI mass spectra of the vitexin following solid phase extraction from $\mathrm{m} / \mathrm{z} 431$

\section{Conclusion}

The relationship between antioxidant properties and total phenolic and flavonoid contents as well as toxicity activity of $F$. deltoidea var. kunstleri's fractions towards the inhibition of prostate cancer was successfully identified. Besides, it was established that SPE method extracted high concentration of antioxidant compounds as compared to the crude extract. Moreover, it also denoted that the extracts of $F$. deltoidea var. kunstleri and its fraction I induced apoptosis activity towards prostate cancer cell line DU145. It was proved as the cells undergo certain morphological changes which indicated the event of apoptosis like DNA blebbing, DNA fragmentation and cell shrinkage. Other than that, study showed that there was a highly correlation of antioxidant activity against prostate cancer. High content of polyphenols including bioactive marker like vitexin play a major role towards prostate cancer inhibition. This study suggested that the fraction $\mathbf{I}$ of $F$. deltoidea var. kunstleri could inhibit the prostate cancer cell line DU145 as same as the crude extracts could by its structure function relationship mechanism revealed by HPLC, FTIR-ATR and LCMS/MS methods. For future studies, it is recommended to use non polar solvent during the extraction method as well as the fractionation using SPE. It is important to discover the effects of non-polar compounds despite the currents study had established cytotoxicity of mostly polar compounds. Besides, due to the presence of polyphenols compounds extracted from the fractions, it is advised to further isolate and purify the fraction to obtain specific compounds.

\section{Acknowledgement}

The corresponding author wishes to thank the Ministry of Education and Universiti Teknologi Malaysia (UTM) under Fundamental Research Grant Scheme (FRGS-R.J130000.7809.4F204) for financing this research project.

\section{References}

1. Li, Y., Ma, D., Sun, D., Wang, C., Zhang, J., Xie, Y. and Guo, T. (2015). Total phenolic, flavonoid content, and antioxidant activity of flour, noodles, and steamed bread made from different colored wheat grains by three milling methods. The Crop Journal, 3(4): 328 - 334.

2. Settharaksa, S., Jongjareonrak, A., Hmadhlu, P., Chansuwan, W. and Siripongvutikorn, S. (2012). Flavonoid, phenolic contents and antioxidant properties of Thai hot curry paste extract and its ingredients as affected of pH, solvent types and high temperature. International Food Research Journal, 19(4): 1581 - 1587.

3. Kefayati, Z., Motamed, S., Shojaii, A., Noori, M. and Ghods, R. (2017). Antioxidant activity and phenolic and flavonoid contents of the extract and subfractions of Euphorbia splendida Mobayen. Pharmacognosy Research, 9(4): 362 - 365. 
4. Wahle, K. J., Brown, I., Rotondo, D. and Heys, S. (2010). Plant phenolics in the prevention and treatment of cancer. In M. Giardi, G. Rea and B. Berra (Eds.). Bio-Farms for Nutraceuticals. United State: Springer: pp. 36 51.

5. Adefegha, S. A. and Oboh. G. (2011). Cooking enhances the antioxidant properties of some tropical green leafy vegetables. African Journal of Biotechnology, 10(4): 632 - 639.

6. Sahreen, S., Khan, M. R. and Khan, R. A. (2014). Effects of Carissa opaca fruits extracts on oxidative pulmonary damages and fibrosis in rats. BMC Complementary and Alternative Medicine, 14(1): 1 - 9.

7. Islam, S., Akhtar, M., Parvez, S., Alam, J. and Alam, F. M. (2013). Antitumor and antibacterial activity of a crude methanol leaf extract of Vitex negundo L. Archives of Biological Sciences, 65(1): 229 - 238.

8. Jain, N. K., Siddiqi, M. A. and Weisburger J. H. (2006). Protective effects of tea on human health. United Kingdom: Cromwell Press.

9. McConnel, T. H. (2007). The nature of disease: Pathology for the health professions. United States: Lippincott Wiliams \& Wilkin.

10. Henry, R.Y. and O'mahony, D. (1999). Treatment of prostate cancer. Journal of Clinical Pharmacy and Therapeutics, 24: 93 - 102.

11. Rang, H. P., Dale, M. M., Ritter, J. M. and Flower, R. J. (2008). Pharmacology. United States: Churchill Livingstone.

12. Farsi, E., Mariam, A. Sook, Y. H., Mohamed B. K. A., Mun, F. Y. and Mohd, Z. A. (2014). Standardized extract of Ficus deltoidea stimulates insulin secretion and blocks hepatic glucose production by regulating the expression of glucose-metabolic genes in streptozitocin induced diabetic rats. BMC Complementary and Alternative Medicine, 14: 220.

13. Corner, E. J. H. (1969). The complex of Ficus deltoidea; a recent invasion of the Sunda Shelf. Philosophical Transactions of the Royal Society of London, 256: 281 - 317.

14. Lee, S. W., Wendy, W., Julius, Y. F. S. and Desy, F. S. (2011). Characterization of antioxidant, antimicrobial, anti cancer property and chemical composition of Ficus deltoidea Jack. Leaf extract. Journal of Biologically Active Products from Nature, 2011: 2231 - 1874.

15. Sulaiman, M. R., Hussain, M. K., Zakaria, Z. A., Somchit, M. N., Moin, S., Mohamad, A. S. and Israf, D. A. (2008). Evaluation of the antinociceptive activity of Ficus deltoidea aqueous extract. Fitoterapia, $79: 557$ - 561.

16. Wahid, S. Mahmud, T. M. M., Maziah, M., Yahya, A. and Rahim, M. A. (2010). Total phenolics content and antioxidant activity of hot water extracts from dried Ficus deltoidea leaves. Journal of Tropical Agriculture and Food Science, 38 (1): 115 - 122.

17. Norra I. (2011). Free radical scavenging activity and phenolic content of Ficus deltoidea accessions MFD4 and MFD6 leaves. Journal of Tropical Agriculture and Food Science, 39(1): 000 -000.

18. Zunoliza, A., Khalid, H., Zhari, I. and Rasadah, M. A. (2009). Anti-inflammatory activity of standardised extracts of leaves of three varieties of Ficus deltoidea. International Journal of Pharmaceutical and Clinical Research, 1(3): 100 - 105.

19. Zakaria, Z. A., Hussain, M. K., Mohamad, A. S., Abdullah, F. C. and Sulaiman, M. R. (2011). Antiinflammatory activity of the aqueous extract of Ficus deltoidea. Biological Research for Nursing, 14(1): 90 97.

20. Sahreen, S., Khan, M. R. and Khan, R. A. (2013). Estimation of flavoniods, antimicrobial, antitumor and anticancer activity of carissa opaca fruits. BMC Complementary and Alternative Medicine, 13(1): 372.

21. Hwa, J. C., Jae, S. E., Bang, G. K., Sun, Y. K., Hoon, J. and Yunjo, S. (2006). Vitexin, a HIF-1 $\alpha$ inhibitor, has anti-metastatic potential in PC12 cells. Molecules and Cells, 22(3): 291 - 299.

22. Hock, E. K., Azrina, A., Amin, I. and Faridah Abas. (2012). Antioxidative properties of defatted dabai pulp and peel prepared by solid phase extraction. Molecules, 17: 9754 - 9773.

23. Petelinc, T., Polak, T., Demšar, L. and Jamnik, P. (2013). Fractionation of phenolic compounds extracted from propolis and their activity in the yeast saccharomyces cerevisiae. PLoS ONE, 8(2): e56104.

24. Vesna, T. T., Sonja, M. D., Jasna, M. C., Gordana, S. C. and Sladana, M. S. (2007). Solid phase extraction of antioxidant compounds from commercial cranberry extract and its antiradical activity. Acta Periodica Technologica, 38: 157 - 164.

25. Theodoridis, G., Lasakova, M., Sherikova, V., Tegou, A., Gianntsiou, N. and Jandera, P. (2006). Molecular imprinting of natural flavonoid antioxidants: Application in solid-phase extraction for the sample pre-treatment of natural products prior to HPLC analysis. Journal of Separation Science, 29: 2310 - 2321. 
Husnul Hanani et al: FRACTIONATION OF AQUEOUS EXTRACT OF Ficus deltoidea VAR. Kunstleri's LEAVES USING SOLID PHASE EXTRACTION METHOD FOR ANTICANCER ACTIVITY ON DU145 CELL LINE

26. Sanagi, M. M., Sulaiman, A. and Ibrahim, W. A. W. (2007). Principles of chemical analysis. (2 ${ }^{\text {nd }}$ edition). Department of Chemistry, Faculty of Science, Universiti Teknologi Malaysia.

27. Ku, Y. R., Liu, Y. C. and Lin, J. H. (2001). Solid-phase extraction and high-performance liquid chromatographic analysis of prednisone adultered in a foreign herbal medicine. Journal of Food and Drug Analysis, 9(3): 150 - 152.

28. Misbah, H., Abdul Aziz, A. and Aminudin, N. (2013). Antidiabetic and antioxidant properties of Ficus deltoidea fruit extracts and fractions. BMC Complementary and Alternative Medicine, 118(13): 1 - 12.

29. Farsi, E., Shafaei, A., Hor, S. Y., Khadeer Ahamed, M. B., Yam, M. F., Attitalla, I. H., Asmawi. M. Z. and Ismail, Z. (2011). Correlation between enzymes inhibitory effects and antioxidant activities of standardized fractions of methanolic extract obtained from Ficus deltoidea leaves. African Journal of Biotechnology, 67(10): 15184 - 15194

30. Anwar, F. and Przybylski, R. (2012). Effect of solvents extraction on total phenolics and antioxidant activity of extracts from flaxseed (Linum usitatissimum L.). Acta Scientiarum Polonorum Technology Aliment, 11(3): 293 -301 .

31. Stankovic, M. S. (2011). Total phenolic content, flavonoid concentration and antioxidant activity of Marrubium peregrinum L. extracts. Kragujevac Journal Science, 33: 63-72.

32. Soib, H. H., Ware, I., Yaakob, H., Mukrish, H. and Sarmidi. M. R. (2015). Antioxidant and anticancer activity of standardized extracts of three varieties of Ficus deltoidea' s leaves. Jurnal Teknologi, 77(3): 19 - 25.

33. Singleton, V. L., Orthofer, R. and Lamuela-Raventos, R. M. (1999). Analysis of total phenols and other oxidation substrates and antioxidants by means of Folin Ciocalteau reagent. Method Enzymology, 299: 152 178.

34. Atanassova, M., Marinova, D. and Ribarova, F. (2005). Total phenolics and total flavonoids in Bulgarian fruits and vegetables. Journal of the University of Chemical Technology Metallurgy, 40: 255 - 260.

35. Patel, H. D., Zaveri, A. D., Zaveri, D. N., Shah, S. and Solanki, A. (2013). Comparison of the MTT and alamar blue assay for in vitro anti-cancer activity by testing of various chalcone and thiosemicarbazone derivatives. International Journal of Pharmaceutical and Biological Sciences, 4 (2): 707 - 716.

36. Elham, F., Shafie, A., Hor, S. Y., Khadeer Ahamed, M. B., Yam, M. F., Asmawi. M. Z. and Ismail, Z. (2013). Genotoxicity and acute and subchronic toxicity studies of a standardized methanolic extract of Ficus deltoidea leaves. Clinics, 68(6): 865 - 875 .

37. Zwir-Ferenc, A. and Biziuk, M. (2006). Solid phase extraction technique-trends, opportunities and applications. Polish Journal of Environmental Studies, 15(5): 677 - 690.

38. Sultana, B., Anwar, F. and Ashraf, M. (2009). Effect of extraction solvent/technique on the antioxidant activity of selected medicinal plant extracts. Molecules, 14: $2167-2180$.

39. Dai, J. and Mumper, R. J. (2010). Plant phenolics: Extraction, analysis and their antioxidant and anticancer properties. Molecules, 15: 7313 - 7352.

40. Khoo, He., Azlan, A., Ismail, A. and Abas F. (2012). Antioxidative properties of defatted dabai pulp and peel prepared by solid phase extraction. Molecules, 17(8): 9754 - 0773.

41. Camel, C. (2003). Solid phase extraction of elements. Spectrochimica Acta, 58(7): 1177 - 1233.

42. Himmat, S. C. (2011). Prospective study of antioxidants, its mechanism and potential role in cancer. International Journal of Research in Pharmaceutical and Biomedical Science, 2(3): 888 - 894.

43. Yizhong, Cai., Qiong, L., Mei, S. and Harold, C. (2003). Antioxidant activity and phenolic compounds of 112 traditional Chinese medicinal plants associated with anticancer. Life Sciences, 74: 2157 - 2184.

44. Mariño, G. and Kroemer, G. (2013). Mechanisms of apoptotic phosphatidylserine exposure. Cell Research, 23(11): 1247 - 1248.

45. Fattahi, S., Ardekani, A. M., Zabihi, E., Abedian, Z., Mostafazadeh, A., Pourbagher, R. and Niaki, A. A. (2013). Antioxidant and apoptotic effects of an aqueous extract of Utica dioica on the MCF-7 human breast cancer cell line. Asian Pacific Journal of Cancer Prevention, 14(9): 5317 - 5323.

46. Demchenko, A. P. (2012). The change of cellular membranes on apoptosis: Fluorescence detection. Experimental Oncology, 34(3): 263 - 268

47. Heerde, W. L. V., Robert-Offerman, S., Dumot, E. A. W. J., Hofstra, L., Doevendans, P. A. and Smits, J. (2000). Markers of apoptosis in cardiovascular tissues: Focus on Annexin V. Cardiovascular Research, 45(3): 549 - 559. 